\title{
PENURUNAN TOTAL KOLONI BAKTERI DAGING AYAM PEDAGING (Gallus domesticus) DI PASAR PAGESANGAN, KOTA MATARAM DENGAN PERLAKUAN INFUSA DAUN SALAM (Syzygium polyanthum)
}

\author{
Ziana Warsani ${ }^{1}$, Suhirman ${ }^{2}$ dan Dwi Wahyudiati ${ }^{3}$ \\ 1Jurusan Pendidikan IPA Biologi FITK IAIN Mataram \\ 2, 3 Dosen Jurusan Pendidikan IPA Biologi FITK IAIN Mataram
}

\begin{abstract}
Abstrak
Tujuan penelitian ini untuk mengetahui pengaruh konsentrasi infusa daun salam dan waktu pengamatan terhadap penurunan jumlah bakteri pada daging ayam pedaging. Penelitian dilakukan secara eksperimental menggunakan rancangan acak lengkap dengan 3 perlakuan yaitu (konsentrasi infusa 0\%, 5\%, 10\%) dan 3 ulangan. Variabel yang diukur meliputi jumlah bakteri. Data total koloni bakteri dianalisis secara kuantitatif menggunakan ANOVA. Hasil analisis data tersebut menunjukkan bahwa F hitung > Ftabel sehingga Ha diterima artinya perendaman dengan konsentrasi infusa daun salam berpengaruh terhadap penurunan total koloni bakteri pada daging ayam pedaging karna senyawa yang terkandung di dalam daun salam seperti tannin, flavonoid, dll.
\end{abstract}

Kata Kunci: Konsentrasi infusa, daun salam (Syzygium polyanthum), koloni bakteri, daging ayam pedaging. 


\section{PENDAHULUAN}

Daging ayam merupakan salah satu bahan pangan yang bernilai gizi tinggi, karena mengandung karbohidrat, protein, lemak, mineral, dan zat lainnya yang berguna bagi tubuh. Daging ayam memiliki rasa yang lezat dan harganya juga relatif murah, sehingga banyak dikonsumsi oleh masyarakat (Situmorang, 2008). Kandungan gizi yang tinggi pada daging merupakan media yang baik bagi pertumbuhan mikroba, sehingga daging merupakan salah satu bahan pangan yang mudah rusak atau perishable. Kerusakan pada daging dapat disebabkan karena adanya aktivitas mikroba (Afrianti, 2013).

Mikroorganisme yang mencemari daging ayam dapat berupa mikroorganisme patogen dan pembusuk. Mikroba patogen dapat menyebabkan Foodborne disease. Sedangkan, Mikroba pembusuk akan menurunkan mutu dan kelayakan karkas serta berpengaruh terhadap nilai ekonomis. Kualitas daging dipengaruhi oleh faktor sebelum dan sesudah pemotongan. Faktor sebelum pemotongan, dapat mempengaruhi kualitas daging antara lain adalah genetik, spesies, dan stres. Faktor setelah pemotongan meliputi proses pemotongan, pelayuan, pembersihan sampai dengan pemasakan (Sugito, 2012). Kontaminasi mikroba pada daging dapat pula terjadi melalui permukaan daging pada saat pembelahan karkas, pendinginan, pembekuan, penyegaran daging beku, pemotongan, pembuatan produk daging olahan, pengawetan, pengepakan, penyimpanan, dan pemasaran (Gustiani, 2009).

Untuk menekan pertumbuhan bakteri, daging ayam umumnya disimpan dengan cara pendiginan, pembekuan, proses termal, dehidrasi (pengeringan), atau dengan pengawetan menggunakan bahan-bahan pengawet seperti garam, gula asam, dan berbagai pengawet kimia atau pengawet sintetis (Lasimpala, 2009). Penggunaan bahan pengawet sintetis dan antioksi pada bahan pangan saat ini tidak direkomendasikan oleh Departemen Kesehatan karena diduga dapat menyebabkan penyakit kanker (carcinogenic agent). Untuk mencegah penggunaan berbagai pengawet kimia berbahaya, serta menjaga keamanan daging ayam 
postmortem di tingkat pedagang, pemanfaatan bahan pengawet alami yang lebih aman perlu dikembangkan. Kebanyakan antioksidan dan antibakteri alami dapat diisolasi dari tanaman, salah satunya adalah daun salam (Syzygium polyanthum) (Agustina, 2012). Daun salam mengandung minyak atsiri, triterpenoid, saponin, flavonoid, dan tannin yang berguna untuk membunuh bakteri patogen, seperti Salmonella sp., Bacillus cereus, B.Subtilis, Staphylococcus aureus, E. coli dan Pseudomonas fluorescens (Dalimarta, 2008).

\section{METODE PENELITIAN}

Penelitian ini merupakan penelitian eksperimental laboratorium. Rancangan penelitian yang digunakan adalah Rancangan Acak Lengkap (RAL) dengan 3 perlakuan (K1: 0\%, K2: 5\%, K3:10\%) dan tiga ulangan. Sampel yang digunakan adalah sembilan sampel daging ayam bagian dada (musculus pectoralis) dengan berat 250 gr dari ayam Broiler yang sudah mencapai masa potong komersial yaitu dengan bobot badan rata-rata 1,5 $\mathrm{kg} /$ ekor.

Variabel yang diteliti adalah total bakteri. Perendaman daging ayam dalam infusa daun salam dilakukan selama 20 menit untuk setiap perlakuan, kecuali kelompok kontrol. Pembuatan infusa daun salam mengacu Ditjen POM RI (1995), yaitu dengan cara menimbang serbuk daun salam sesuai kebutuhan. Untuk pembuatan infusa berkadar zat aktif 5\%, maka serbuk daun salam yang dibutuhkan $50 \mathrm{~g}$ ditambah air sampai volume $1000 \mathrm{ml}$, sementara pembuatan infusa berkadar zat aktif $10 \%$, maka serbuk daun salam yang dibutuhkan $100 \mathrm{~g}$ ditambah air sampai volume $1000 \mathrm{ml}$ yaitu 0 jam, 5 jam dan 10 jam. Penurunan total koloni mulai dihitunng pada 10 jam waktu pengamatan (lama penyimpanan).

Penghitungan jumlah bakteri dilakukan dengan metode Total Plate Count (TPC), yaitu cara penghitungan jumlah mikroba yang terdapat dalam suatu produk yang tumbuh pada media agar, pada suhu dan waktu inkubasi yang telah ditetapkan. Prinsip dari TPC dimaksudkan untuk menunjukkan jumlah 
mikroba yang terdapat dalam suatu produk dengan cara menghitung koloni bakteri yang tumbuh pada media agar. Penurunan total koloni dilihat pada 3 waktu pengamatan. Data penghitungan total bakteri ditabulasi dan dianalisis secara kuantitatif dengan uji statistik Anava pada taraf uji 5\%. Apabila hasil uji Anava menunjukkan perbedaan, maka analisis dilanjutkan dengan uji BNT pada $\alpha=5 \%$.

\section{HASIL DAN PEMBAHASAN}

Data total bakteri yang terdapat pada daging ayam pada tiga aras konsentrasi infusa pada 10 jam waktu pengamatan terlihat pada Tabel 1.

\section{Tabel 1}

Data Penurunan Total Koloni Bakteri Daging Ayam Pedaging Dengan Perlakuan Infusa Daun Salam

\begin{tabular}{|c|c|c|c|c|c|}
\hline \multirow{2}{*}{$\begin{array}{c}\text { Konsentrasi } \\
\text { Infusa Daun } \\
\text { Salam (\%) }\end{array}$} & \multicolumn{3}{|c|}{ Ulangan } & \multirow{2}{*}{ Jumlah } & \multirow{2}{*}{$\begin{array}{c}\text { Rata-rata }\left(10^{5}\right. \\
\left.\mathrm{cfu} / \mathrm{cm}^{2}\right)\end{array}$} \\
\hline & 1 & 2 & 3 & & \\
\hline$K_{1}(0 \%)$ & 347 & 277 & 213 & 837 & $279^{a}$ \\
\hline$K_{2}(5 \%)$ & 102 & 64 & 55 & 221 & $73,67^{b}$ \\
\hline$K_{3}(10 \%)$ & 1 & 65 & 69 & 135 & $45^{b}$ \\
\hline Rata-rata & 150 & 135,33 & 112,33 & & \\
\hline
\end{tabular}

Keterangan: superskrip huruf yang berbeda pada baris menunjukkan perbedaan nyata pada taraf $5 \%$ menurut uji BNT.

Tabel 1 menunjukkan bahwa rata- rata total bakteri terbanyak diperoleh pada sampel daging ayam kontrol (tanpa perendaman infusa) pada jam ke-10 setelah perendaman dan total bakteri cenderung menurun pada daging ayam yang diberikan perlakuan infusa daun 
salam, peningkatan konsentrasi infusa daun salam dari 5\% sampai dengan $10 \%$ diikuti dengan penurunan jumlah bakteri. Untuk lebih jelasnya perbandingan total bakteri pada daging ayam yang diberikan perlakuan infusa daun salam dan waktu pengamatan yang berbeda ditunjukkan oleh Gambar 1 .

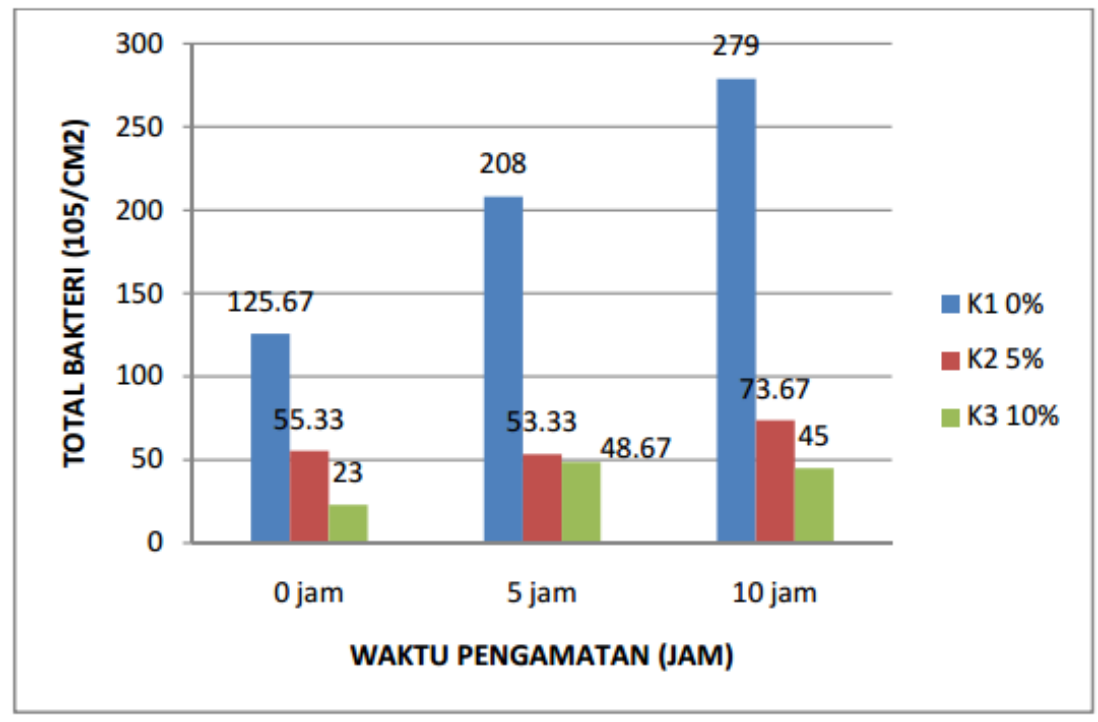

Gambar 1. Grafik Total bakteri pada konsentrasi infusa daun salam dan waktu pengamatan yang berbeda

Berdasarkan data pada Gambar 1 menunjukkan bahwa penggunaan infusa daun salam $5 \%$ dan $10 \%$ pada setiap jam pengamatan yaitu 0 jam, 5 jam dan 10 jam mampu menurunkan total koloni bakteri yang ada pada daging ayam, terlihat bahwa total koloni terbanyak terdapat pada sampel daging ayam kelompok control, namun cenderung menurun pada sampel daging ayam yang diberi perlakuan infusa daun salam dengan konsentrasi 5\% dan 10\%.

Analisis sidik ragam dilakukan untuk mengetahui pengaruh perlakuan konsentrasi infusa daun salam terhadap penurunan total koloni bakteri daging ayam pedaging di pasar tradisional Pagesangan, Kota Mataram. Hasil analisis sidik ragam pengaruh perendaman infusa daun salam (Syzygium polyanthum) menunjukkan bahwa ada pengaruh perendaman infusa daun 222 BIOTA: Jurnal Tadris IPA Biologi FITK IAIN Mataram 
salam $5 \%$ dan $10 \%$ terhadap penurunan total koloni bakteri pada daging ayam pedaging.

Berdasarkan hasil uji BNT (beda nyata terkecil) dapat dijelaskan bahwa total bakteri terendah $(45 \times 105$ CFU/cm2) pada perlakuan perendaman daun salam 10\% tidak berbeda nyata dengan perlakuan konsentrasi 5\%, tetapi nyata berbeda dibandingkan dengan perlakuan konsentrasi 0\% (tanpa daun salam). Hal ini menunjukkan bahwa konsentrasi perendaman daun salam $10 \%$ adalah konsentrasi terbaik karena kemungkinan tingginya senyawa antibakteri tanin dan flavanoid pada perlakuan tersebut. Tanin, minyak atsiri, flavonoid, dan saponin memiliki kemampuan untuk menghambat pertumbuhan bakteri.

Mekanisme kerja tanin sebagai antimikroba berhubungan dengan kemampuan tanin dalam menginativasi adhesin sel mikroba (molekul yang menempel pada sel inang) yang terdapat pada permukaan sel dan tanin memiliki sasaran terhadap polipeptida dinding sel yang menyebabkan kerusakan pada dinding sel. Tanin, dalam konsentrasi rendah mampu menghambat pertumbuhan kuman, sedangkan pada konsentrasi tinggi, tannin bekerja sebagai antimikroba dengan cara mengkoagulasi atau menggumpalkan protoplasma kuman, sehingga terbentuk ikatan yang stabil dengan protein mikroorganisme (Setiawan, 2002).

Tannin merupakan senyawa yang mendominasi pada daun salam dibandingkan senyawa yang lain seperti minyak atsiri, flavonoid, dll, sehingga pemilihan daun salam yang tua atau yang muda untuk digunakan akan mempengaruhi kadar tannin yang terdapat didalamnya. Berdasarkan hasil studi literature tentang menetapan kadar tannin menyatakan bahwa Kandungan tanin pada daun salam yang lebih tua lebih tinggi dibandingkan pada daun salam yang lebih muda usianya. Hasil penetapan kadar tannin dalam sampel infusa daun salam muda dan daun salam tua berturut-turut 2,38 $\pm 0,036 \%$ (KV=1,51\%) dan 2,45 $\pm 0,007 \%$ (KV=0,29\%) (Mufti, 2002). Pada penelitian ini menggunakan daun salam yang usianya sudah tua sehingga kadar tannin yang 
diperoleh mampu mengakibatkan terjadinya perubahan sistem fisiologis sel bakteri yang pada akhirnya akan menyebabkan kematian pada sel bakteri. Pertumbuhan bakteri pada daging ayam selain dipengaruhi oleh perlakuan konsentrasi infusa daun salam, juga dipengaruhi oleh lama waktu penyimpanan. Hal ini sejalan dengan penelitian suwono., dkk (2009), terjadi penurunan total bakteri Streptococcus sp. Setelah diberikan perlakuan rebusan daun salam pada waktu pengamatan 6 jam (Suwono, 2009). Begitu pula dengan hasil penelitian Fitri (2007), menyatakan bahwa semakin tinggi konsentrasi daun salam yang ditambahkan, akan semakin memperlambat peningkatan jumlah bakteri $S$. aureus pada telur asin. Hal ini memperlihatkan bahwa daun salam yang digunakan pada penelitian ini mempunyai aktivitas antibakteri terhadap bakteri S. aureus. Daya antibakteri pada daun salam disebabkan oleh kandungan senyawanya seperti tanin, minyak atsiri dan flavonoid.

\section{KESIMPULAN}

Berdasarkan hasil dapat disimpulkan bahwa konsentrasi infusa daun berpengaruh nyata terhadap total bakteri daging ayam pedaging karna senyawa yang dikandung oleh daun salam yaitu tannin mampu mengakibatkan perubahan pada sistem fisiologis sel.

\section{DAFTAR PUSTAKA}

Afrianti, Melda., Dkk. 2013, “Total Bakteri, Ph, Dan Kadar Air Daging Ayam Broiler Setelah Direndam Dengan Ekstrak Daun Senduduk (Melastoma malabathricum l.) Selama Masa Simpan". Jurnal Pangan dan Gizi, No. 07,Vol. 04, h. 49.

Mufti, dkk. 2009. Penetapan Kadar Tannin Dalam Infusa Daun Salam (Syzygium polyanthum (wight.) Walp)) Secara Spektrofotometri Sinar Tampak. Pharmacy. Vol. 06 no. 01. Hal 27

224 BIOTA: Jurnal Tadris IPA Biologi FITK IAIN Mataram 
Agustina, dkk. 2012. "Efek Perendaman Infusa Daun Salam (Syzygium Polyanthum) Terhadap Kualitas Daging Ayam Postmortem", Biosaintifika, No. 4, Vol. 2, h. 79. Dalimarta, Resep Tumbuhan Obat Untuk Asam Urat, (Jakarta: Penebar Swadaya 2008) h. 50.

Fitri, Ana. 2007. Pengaruh Penambahan Daun Salam (Eugenia Polyantha Wight) Terhadap Kualitas Mikrobiologis, Kualitas Organoleptis Dan Daya Simpan Telur Asin Pada Suhu Kamar, ("Skripsi", Surakarta, Univ. Sebelas Maret) h. 55

Gustiani, Erni. 2009. "Pengendalian Cemaran Mikroba Pada Bahan Pangan Asal Ternak (Daging Dan Susu) Mulai Dari Peternakan Sampal Dihidangkan". Jurnal Litbang Pertanian, N0. 28, Vol. 3, h: 98.

Sugito, dkk. 2010. "Pertambahan Bobot Badan Dan Waktu Pembusukan Daging Ayam Broiler Yang Diberi Ekstrak Jaloh Dikombinasi Dengan Kromium". Agripet. No. 2, Vol. 10, h. 22.

Setiawan. 2002. "Pengaruh perlakuan kimia dan fisik terhadap aktivitas antimikroba daun salam (Syzygium polyanthum (Wight) Walp)" (Skripsi. Fakultas Teknologi Pertanian, IPB, Bogor h. 29-30.

Situmorang, EN. 2008. "Pengawetan Daging Ayam (Gallus gallus domesticus) Dengan Larutan Garam Dingin" (Skripsi, Universitas Sumatra Utara, Medan) h. 18.

Suwono A \& Agustin. 2009. Kemampuan air rebusan daun salam dalam menurunkan jumlah koloni bakteri Streptococcus sp. Majalah Farmasi Indonesia. 20:112-117. 